From Micro-Powers to Governmentality:

Foucault's Work on Statehood, State Formation, Statecraft and State Power

\author{
Bob Jessop \\ Professor of Sociology and IAS Director, \\ Institute for Advanced Studies \\ County College South \\ Lancaster University \\ Lancaster LA1 1YQ \\ r.jessop@lancaster.ac.uk \\ (+44) 1524510812 \\ (+44) 1524594256
}




\begin{abstract}
:
This article revisits Foucault's analytics of power in the light of his lectures on governmentality and biopolitics in Society must be Defended (1975-6), Securité, territoire, population (1977-8) and Naissance de la biopolitique (1978-9). Foucault is renowned for his criticisms of state theory and advocacy of a bottom-up approach to social power; and for his hostility to many theoretical and practical manifestations of orthodox Marxism. Yet these lectures, especially those on governmentality, are directly and explicitly concerned with statehood, state formation, statecraft, and state power and the subsequent role of new forms of government and political calculation in guiding capitalist reproduction. They cast new light on Foucault's alleged antistatism and anti-Marxism and offer new insights into his restless intellectual development. Accordingly, this article reviews Foucault's hostility to Marxism and theories of the state, considers his apparent turn from the micro-physics and microdiversity of power relations to their macro-physics and strategic codification through the governmentalized state, and suggests how to develop an evolutionary account of state formation on the basis of these new arguments about emerging forms of statecraft.
\end{abstract}

Keywords: Foucault; power; governmentality; state formation; statecraft; evolutionary analysis.

Running title: From Micropowers to Governmentality 


\section{From Micro-Powers to Governmentality: Foucault's Work on Statehood, State Formation, Statecraft and State Power}

\section{Bob Jessop}

Foucault is renowned for his criticisms of state theory and advocacy of a bottom-up approach to social power as well as for his hostility to orthodox Marxism and communist political practice. Yet there have always been indications in his work that matters are not so simple, especially in his work during the mid-to-late 1970s. The recent publication in full of his lectures on governmentality and biopolitics in Society must be Defended (1975-6), Securité, territoire, population (1977-8) and Naissance de la biopolitique (1978-9) cast new light on this topic. For they mark a decisive turn, especially those on governmentality, to changing forms of statehood and statecraft and their subsequent role in guiding capitalist reproduction. They cast new light on Foucault's alleged anti-statism and anti-Marxism and offer new insights into his restless intellectual development. To show this, I review Foucault's hostility to Marxism and theories of the state, consider his apparent turn from the micro-physics and micro-diversity of power relations to their macro-physics and strategic codification through the governmentalized state, and suggest how to develop an evolutionary account of state formation on the basis of these new arguments about emerging forms of statecraft. This intervention does not aim to reveal the essence of Foucault's interest in governmentality but to offer another reading alongside conventional accounts of this stage in his work.

\section{FOUCAULT AND THE "CRISIS OF MARXISM"}

Foucault's work reveals the paradox of an outspoken opposition to official and vulgar Marxist positions and an implicit appropriation and development of insights from Marx himself. May 1968 was a major turning point in this regard, according to Foucault himself, because it signalled a crisis in official Marxism and serious ruptures in a modern capitalist society. In criticizing Marxism, Foucault rarely identified specific theorists, preferring general problematization to detailed critique (Fontana and Bernati 2003: 287). At different times he rejected vulgar Marxism; Freudo-Marxism; academic (or university) Marxism; para-Marxism; treatments of 
labour as man's concrete essence; 'endless commentaries on surplus-value'; abstract interest in 'class' rather than detailed studies of the subjects, stakes, and modalities of 'class' struggle; the grounding of power in the economy and/or class relations; the reduction of the state to a set of functions, such as managing productive forces and relations; concern with consciousness and ideology rather than the materiality of the body and anatomo-politics; epiphenomenalist analyses of infrastructure and superstructure relations; the sterility of dialectics and the logic of contradiction; the 'hypermarxification' of social and political analyses; Marxist hagiography; and 'communistology'; and Marxist claims to scientificity to the exclusion of other forms of knowledge (see especially the articles, lectures, and interviews in Foucault 1994).

Despite this, "Foucault maintained a sort of "uninterrupted dialogue" with Marx, [who] was in fact not unaware of the question of power and its disciplines' (Fontana and Bertani 2003: 277). While he maintained that Marx's analysis of value stayed within the classic episteme of Smith and Ricardo, Foucault praised Marx's epistemic break in the fields of history and politics. This is reflected in increasingly sympathetic but often covert references to some core themes in Marx's critique of political economy and, even more importantly, his historical analyses, some of them deliberately and provocatively undeclared (Balibar 1992; Kalyvas 2002; MacDonald 2002; Lemke 2003; Elden 2007). Thus Foucault began to argue that capitalism has penetrated deeply into our existence, especially as it required diverse techniques of power to enable capital to exploit people's bodies and their time, transforming them into labour power and labour time respectively to create surplus profit (1977: 163, 174-5; 1979: 37, 120-4, 140-1; and 2003: 32-37; see also Marsden 1999). This prompted Balibar to suggest that Foucault moved from a break to a tactical alliance with Marxism,

[with] the first involving a global critique of Marxism as a "theory"; the second a partial usage of Marxist tenets or affirmations compatible with Marxism. ...Thus, in contradictory fashion, the opposition to Marxist "theory" grows deeper and deeper whilst the convergence of the analyses and concepts taken from Marx becomes more and more significant (Balibar 1992: 53).

\section{THE ANALYTICS OF POWER VERSUS STATE THEORY}


In addition to his general antipathy to Marxism, Foucault also claimed that 'I do, I want to, and I must pass on state theory - just as one would with an indigestible meal' (2004b: 78, my translation). This is reflected in his well-known hostility to general theorizations about the state - whether juridico-political, Marxist, or realist and his grounding of power and control in the modern state, to the extent that the latter exists, in social norms and institutions and distinctive forms of knowledge rather than in sovereign authority. Foucault stressed three themes in his 'nominalist' analytics of power: it is immanent in all social relations, articulated with discourses as well as institutions, and necessarily polyvalent because its impact and significance vary with how social relations, discourses and institutions are integrated into different strategies. He also focused on technologies of power, power-knowledge relations, and changing strategies for structuring and deploying power relations. In developing this analytics of power, Foucault rejected attempts to develop any general theory about state power - or power more generally - based on a priori assumptions about its essential unity, its pre-given functions, its inherent tendency to expand through its own power dynamics, or its global strategic deployment by a master subject (see especially Foucault 1979, 1980; cf. 2003: 27-31; 2004b: 79, 193-4).

Based on his early comments, which were largely recapitulated in his courses at the Collège de France on biopolitics and governmentality from 1975-1979, Foucault's analytics of power can be summarized as follows. The study of power should begin from below, in the heterogeneous and dispersed microphysics of power, explore specific forms of its exercise in different institutional sites, and consider how, if at all, these were linked to produce broader and more persistent societal configurations. One should study power where it is exercised over individuals rather than legitimated at the centre; explore the actual practices of subjugation rather than the intentions that guide attempts at domination; and recognize that power circulates through networks rather than being applied at particular points (Foucault 1979: 92-102; 2003: 27-34). However, following this initial move, Foucault also began to emphasize that, whilst starting at the bottom with the micro-diversity of power relations across a multiplicity of dispersed sites, two further interrelated issues required attention: first, how do diverse power relations come to be colonized and articulated into more general mechanisms that sustain more encompassing forms of domination and, 
second, how are they linked to specific forms and means of producing knowledge?

It is in this context that Foucault developed the problematic of government to explore the historical constitution and periodization of the state and the important strategic and tactical dimensions of power relations and their associated discourses. For, in rejecting various essentialist, transhistorical, universal, and deductive analyses of the state and state power, Foucault created a space for exploring its 'polymorphous crystallization,1 in and through interrelated changes in technologies of power, objects of governance, governmental projects, and modes of political calculation. Indeed, he argued that 'the state is nothing more than the mobile effect of a regime of multiple governmentalities' (2004b: 79). For Foucault, this does not mean that one needs a transhistorical, universal notion of the state before deconstructing it in and through an interrogation of historically specific, concrete practices. He avoids this paradox by asking how one might explore history if the state did not always-already exist (2004b: 4-5). For example, Society Must be Defended shows how the modern idea of the universal state emerged from a complex series of discursive shifts and the eventual combination of disciplinary and biopolitical power within a redefined framework of sovereignty (2003: $37-9,242-50)$. Let us see what it means to explore the historical emergence of 'state effects' as revealed in last two series of lectures of interest here.

\section{FOUCAULT AS A GENEALOGIST OF STATECRAFT}

Although Foucault often refers to the state, he refused to take its existence for granted and rejected any state theory based on this assumption. The current texts reiterate that the state has no essence, is not a universal, is not an autonomous source of power. Instead it is an emergent and changeable effect of incessant transactions, multiple governmentalities, perpetual statizations (2004b: 79).

An analysis in terms of power must not assume that state sovereignty, the form of the law, or the over-all unity of a domination, is given at the outset; rather, these are only the terminal forms power takes. ... power must be understood in the first instance as the multiplicity of force relations immanent in the sphere in which they operate and that constitute their own organization; as the process which, through ceaseless struggles and confrontations, 
transforms, strengthens, or reverses them; as the support which these force relations find in one another, thus forming a chain or a system, or, on the contrary, the disjunctions and contradictions that isolate them from each other; and, lastly, as the strategies in which they take effect, whose general design or institutional crystallization is embodied in the state apparatus, in the formulation of the law, in various social hegemonies. Power's condition of possibility [and its role as a] grid of intelligibility of the social order must not be sought in the primary existence of a central point, in a unique source of sovereignty from which secondary and derived forms might emanate; it is the moving substrate of force relations which, by virtue of their inequality, constantly engender states of power, but the latter are always local and unstable. ... Power is everywhere; not because it embraces everything, but because it comes from everywhere (2004b: 92-3, my translation).

In this context, the art of government, or governmentality, is said to involve 'the ensemble constituted by the institutions, procedures, analyses, and reflections, the calculations and tactics that permit the exercise of this quite specific, albeit very complex form of power, which has, as its principal target, population; as its main form of knowledge, political economy; and, as its essential technical means, apparatuses of security' (2004a: 111, my translation). Thus Foucault regards the state as a relational ensemble and treats governmentality as a set of practices and strategies, governmental projects and modes of calculation, that operate on the something called the state. This something is terrain of a non-essentialized set of political relations, however, rather than a universal, fixed, unchanging phenomenon. In this sense, while the state is pre-given as an object of governance, it also gets reconstructed as government practices change (2004b: 5-6).

In short, to study governmentality in its generic sense is to study the historical constitution of different state forms in and through changing practices of government without assuming that the state has a universal or general essence. This is why Foucault criticized analyses of the state (and/or states) as a juridico-political instance, a calculating subject, an instrument of class rule, or an epiphenomenon of production relations. Nonetheless, whilst eschewing any general theory of the state, 
he certainly explored emergent strategies (state projects, governmentalizing projects) that identified the nature and purposes of government (as reflected in alternative forms of raison d'état) in different contexts and periods. In particular, his Collège de France lectures from 1975 to 1979 argued that disciplinary power was later supplemented by the emergence of biopolitics and security as new forms of ratio gouvernmentale. While disciplinary power could compensate for the failure of sovereign power at the level of individual bodies, the harder task of controlling the population was only resolved with the development of biopolitics.

This was a core theme of the last two sets of lecture considered here. They studied changing theories and practices about the art of government as well as the changing institutions and institutional ensembles with which such practices were linked. Thus Foucault identified three forms of government: sovereignty, disciplinarity, and governmentality. The first is associated with the medieval state based on customary law, written law, and litigation and concerned with control over land and wealth; the second with the rise of the administrative state of the $15^{\text {th }}$ and $16^{\text {th }}$ century based on the disciplinary regulation of individual bodies in different institutional contexts; and the third with the increasingly governmentalized state, which dates from the late $16^{\text {th }}$ and came to fruition in the $19^{\text {th }}$ century, when state concern was henceforth focused on controlling the mass of the population on its territory rather than controlling territoriality as such (2004a: 221; cf., with the same sequence but other dates, 2003: 37-9, 249-250). Expanding this account, Foucault traced governmental concerns back to $16^{\text {th }}$ century interest in the administration of territorial monarchies; to $16^{\text {th }}$ and $17^{\text {th }}$ century development of new analyses and forms of 'statistical' knowledge, i.e., knowledge of the state, in all its elements, dimensions, and factors of power; and, finally, to the rise of mercantilism, cameralism, and Polizeiwissenschaft (2004a: 212). Accordingly, the governmental state arose from the governmentalization of the state rather than the statization of society and was based on continual (re)definition of state competences and the division between public and private (2004a: 220-1).

\section{WITH FOUCAULT BEYOND FOUCAULT}

Some of the ambiguities and confusions surrounding Foucault's analyses of power and its significance in social life can be resolved if we distinguish three moments in 
the development of power relations. These are variation in the objects, subjects, purposes, and technologies of power; selection of some technologies and practices rather than others; and retention of some of these in turn as they are integrated into broader and more stable strategies of state and/or class (or national or racial) power. These three moments overlap and interact in real time but Foucault tended to come to them (or, at least, elaborate them) separately in his work, focusing first on genealogical variation, then on the emergent convergence and selection of various technologies of power to delineate general conditions of domination as they are seen to have economic or political utility for an emerging bourgeoisie, and finally on the strategic codification and retention of these practices of government to produce a global strategy oriented to a more or less unified objective. The first step in this trajectory introduces the familiar notion of genealogy - which many observers see as a central contribution of these and earlier texts, building on, but never superseding, his archaeological analyses. Far more interesting, however, is the marked extent to which its second and, even more, its third step re-introduce state power. Foucault now treats state power as a crucial emergent field of strategic action and connects it both to issues of capitalist political economy and to the interests of an emerging bourgeois class; but he never regards the state, capital, or the bourgeoisie as preconstituted forces, treating them instead as emergent effects of multiple projects, practices, and attempts to institutionalize political power relations. Foucault's reference to capitalist and bourgeois forces is often noted but few commentators identify its crucial relevance for an anti-essentialist, non-teleological, ex post functionalist explanation of capitalist development and state formation.

Three points are worth noting here. First, following his more general rejection of attempts to provide a totalizing account of social events, Foucault typically rejected any a priori assumption that different forms of power were connected to produce an overall pattern of class domination. He noted that the modern state's disciplinary techniques originated in dispersed local sites well away from the centres of state power in the Ancien Régime and well away from emerging sites of capitalist production and had their own distinctive disciplinary logics. Thus disciplinary normalization focused on the conduct of persons who were not directly involved in capitalist production (e.g., in asylums, prisons, schools, barracks). Nonetheless, second, Foucault recognized that some technologies and practices were selected 
and integrated into other sites of power. Thus, while Discipline and Punish (1977) mostly emphasized the dispersion of power mechanisms, the first volume of the History of Sexuality (1979) began to explore how different mechanisms were combined to produce social order through a strategic codification that made them more coherent and complementary. In this text and a roughly contemporary lecture series, Society Must be Defended, Foucault links this explicitly to bourgeois recognition of their economic profitability and political utility $(1979$ : 114, 125, 141; 2003: 30-33). Third, he explored how existing power relations were not only codified but also consolidated and institutionalized. Thus Foucault notes how the immanent multiplicity of relations and techniques of power are 'colonised, used, inflected, transformed, displaced, extended, and so on by increasingly general mechanisms and forms of overall domination ... and, above all, how they are invested or annexed by global phenomena and how more general powers or economic benefits can slip into the play of these technologies of power' (2003: 30-1).

This codification and consolidation occurred in quite specific historical conditions that, according to Foucault, cannot be derived from the functional needs of the economy but have their own pre-history and developmental dynamic. For example, Foucault argues that only a post-sovereign state could consolidate the new forms of government insofar as the emergence of the problem of population enabled power to be refocused on the economy rather than the family writ large (2004a: 214-15). The articulation of the economic and political should not be explained in terms of functional subordination or formal isomorphism (2003: 14). Instead it should be studied in terms of functional overdetermination and a perpetual process of strategic elaboration or completion. The former occurs when 'each effect - positive or negative, intentional or unintentional - enters into resonance or contradiction with the others and thereby calls for a readjustment or a re-working of the heterogeneous elements that surface at various points' (1980: 195). In describing the strategic elaboration or completion of a general line, Foucault invoked concepts such as 'social hegemonies', 'hegemonic effects', 'hegemony of the bourgeoisie', 'metapower', 'class domination', 'polymorphous techniques of subjugation', 'sur-pouvoir' (or a 'surplus power' analogous to surplus value), 'global strategy', and so forth. He also gave a privileged role to the state as the point of strategic codification of the multitude of power relations and the apparatus in which the general line is 
crystallized (e.g., 2003: 27, 31-35; cf. 1980: 122, 156, 189, 199-200; 1982: 224). For example, it was the rise of the population-territory-wealth nexus in political economy and police created the space for the revalorization and re-articulation of disciplines that had emerged in 17th and 18th century, i.e., schools, manufactories, armies, etc (2004a: 217-19).

In approaching Foucault's work in these terms, we can escape the dichotomy of micro- and macro-power, the antinomy of an analytics of micropowers and a theory of sovereignty, and the problematic relation between micro-diversity and macronecessity in power relations (cf. Jessop 1990; Kerr 1999: 176). The idea of government as strategic codification of power relations provides a bridge between micro-diversity and macro-necessity and, as Foucault argues, a focus on micropowers is determined by scale but applies across all scales. It is a perspective, not a reality delimited to one scale (2004b: 193; cf. 2003: 244). Introducing the concept of biopolitics requires Foucault to say more about the global strategies of the state and the 'general line of force that traverses local confrontations' and links them together' (1980: 94). In this way we can move from the analysis of variation to the crucial issues of selection and retention that produce a distinctive articulation of the economic and political in particular historical contexts.

\section{CONCLUSIONS}

Foucault always rejected attempts to develop a general theory and changed direction and argument according to his changing interests and the changing political conjuncture. This is why we should not seek an 'essential Foucault'. Nonetheless the three lecture courses on governmentality $(2003,2004 a, 2004 b)$ indicate increasing interest in complex and contingent problems of political economy and statecraft. Foucault certainly rejected crude 'capital-logic' arguments about socio-economic development and state-centric accounts of the state. But his 'critical and effective histories' were increasingly brought to bear in the mid-to-late 1970s on questions of political economy and the historical constitution of the state from the $16^{\text {th }}$ to $20^{\text {th }}$ centuries. His novel and highly productive approach also showed how the economy and the state were increasingly organized in conformity with key features of capitalist political economy without ever being reducible thereto and without these features in 
turn being fully pre-given. In this sense, generalizing from Marsden's re-reading of Marx and Foucault on capitalism (1999), it seems that, while Marx seeks to explain the why of capital accumulation and state power, Foucault's analyses of disciplinarity and governmentality try to explain the how of economic exploitation and political domination (on the importance of 'how' questions for Foucault, see his 1982). There is far more, of course, to Foucault's work in this period but this re-reading shows that there is more scope than many believe for dialogue between critical Marxist and Foucauldian analyses.

\section{References}

Balibar, E. (1992) Foucault and Marx: the Question of Nominalism. In Michel Foucault, Philosopher, ed., T.J. Armstrong, pp. 38-56. London: Routledge.

Elden, S. (2006) Rethinking governmentality, this issue.

Fontana, A. and Bertani, M. (2003) Situating the Lectures. In "Society must be Defended". Lectures at the Collège de France 1975-1976, pp. 273-293. New York: Picador, 273-93.

Foucault, M. (1977) Discipline and Punish: The Birth of a Prison. London: Allen Lane.

Foucault, M. (1979) The History of Sexuality, vol 1. An Introduction. London: Allen Lane.

Foucault, M. (1980) Power/Knowledge. Selected Interviews and Other Writings 1972-1977. New York: Pantheon.

Foucault, M. (1982) How is power exercised? In Michel Foucault: Beyond Structuralism and Hermeneutics, eds, H.L. Dreyfus and P. Rabinow, pp. 216226. Brighton: Harvester Press.

Foucault, M. (1994) Dits et Ecrits. Paris: Gallimard.

Foucault, M. (2003) "Society must be defended". Lectures at the Collège de France 1975-1976. New York: Picador.

Foucault, M. (2004a) Securité, territoire, population. Cours au Collège de France, 1977-1978. Paris: Seuil/Gallimard.

Foucault, M. (2004b) Naissance de la biopolitique. Cours au Collège de France, 1978-1979. Paris: Seuil/Gallimard.

Kalyvas, A. (2004) The stateless theory. Poulantzas's challenge to postmodernism. 
In Paradigm Lost: State Theory Reconsidered, eds, S. Aronowitz and P. Bratsis, pp. 105-142. Minneapolis: University of Minnesota Press.

Kerr, D. (1999) Beheading the King and enthroning the market: a critique of Foucauldian governmentality. Science \& Society 63 (2), 173-202.

Lemke, T. (2003) Andere Affirmationen. Gesellschaftsanalyse und Kritik im Postfordismus. In Zwischenbilanz einer Rezeption eds, A. Honneth and M. Saar, pp. 259-274. Frankfurt: Suhrkamp.

MacDonald, B.J. (2002) Marx, Foucault, genealogy. Polity 34 (3), 259-284.

Mann, M. (1986) The Sources of Social Power, vol. 1. Cambridge: Cambridge University Press.

Marsden, R. (1999) The Nature of Capital: Marx after Foucault. London: Routledge. Sheridan, A. (1980) Michel Foucault: the Will to Truth. London: Tavistock.

\section{Endnote}

1 The concept of 'polymorphous crystallization' was introduced by Mann (1986) to highlight how specific configurations of the state apparatus and state power derive from the differential articulation of various elements of the state under the dominance of four alternative political projects - economic, military, democratic, or ideological. 